\title{
Doctrine of Good Faith in Contracts: A Comparison between Conventional and Islamic Laws
}

\author{
Yusuf Sani Abubakar', Ahamad Faosiy Ogunbado ${ }^{2}$, Mpawenimana Abdallah Saidi ${ }^{3}$ \\ ${ }^{1}$ Islamic Business School, College of Business, Universiti Utara Malaysia (UUM) Sintok Kedah, \\ Malaysia \\ ${ }^{2}$ Faculty of Islamic Development Management Universiti Islam Sultan Sharif Ali (UNISSA), Brunei, \\ Darussalam \\ ${ }^{3}$ Universiti Malaysia Sarawak (UNIMAS), Sarawak, Malaysia) \\ 'yusuf700@gmail.com, ${ }^{1}$ Yusufsani@uum.edu.my
}

\begin{abstract}
The doctrine of good faith is a vital issue amongst the contractual issues of this period .It is considered a main goal of every recognized law of contract system to be promoting good faith as well as fair dealing in forming and performance of contracts. Basically, it has been a common argument in supporting the notion of good faith that it helps in addressing bad faith manner in a clear and direct conduct, allow the law to safeguard the realistic anticipations of women and men as well as encourage a philosophy of contractual collaboration that would lead to economic efficiency. This study looks into the concept of good faith from both the conventional law and Islamic law (Shariah) to find to what extent both laws comply with each other. The study is doctrinal which utilizes descriptive approach of qualitative research methodology which relies on secondary data in form of text books, journals, newspapers, related websites etc. The study found that both the conventional law and Islamic law support the principle of good faith. Shariah recognized the principle of good faith as it asks the parties in a contract to abide by the requirement in various stages of the contract, especially sale contract. Thus, the concept of good faith should have the same application in both Islamic and conventional jurisdictions.
\end{abstract}

KEYWORDS: Good Faith, Islamic law (Shariah), Contract, Canon law, Rules of equity.

\section{INTRODUCTION}

The doctrine of good faith is a vital issue amongst the contractual issues of this period Harrison ${ }^{14}$. It is considered a main goal of every recognized law of contract system to be promoting good faith as well as fair dealing in forming and performance of contracts (Johan 2004). Basically, it has been a common argument in supporting the notion of good faith that it helps in addressing bad faith manner in a clear and direct conduct, allow the law to safeguard the realistic anticipations of women and men as well as encourage a philosophy of contractual collaboration that would lead to economic efficiency Brownsword ${ }^{4}$.

Historically, the origin of the good faith concept goes back to Roman law. Just similar to equity of the English law, the limits of a recognized procedure in Roman law were overcome by actions taken by those given the responsibility of the administration of justice. Roman law was an example of the first legal system to adapt through the impact of equitable concepts Schermaier ${ }^{30}$. The ancient and famous procedure in the Roman law was later termed as legis actio (act or sue according to the law) Mousourakis ${ }^{22}$.

As for the history of good faith in the medieval ius Commune, certainly, the ius commune strengthened its established status as a part of Christian culture of Europe by the 14th century. The said scenario led to religion as well as law to be thoroughly linked in the late medieval writing Stein ${ }^{31}$. Actually, the medieval jurists who learnt canon and Roman laws clearly accepted the notion of good faith and equity in contract (Gordley). 